\title{
Asystent rodziny jako forma wsparcia rodziny z wieloma problemami
}

\author{
Family assistant as a form of support provided \\ to a multi-problem family
}

\begin{abstract}
Many modern families face problems that hinder optimum functioning as a family or make it even impossible. Numerous overlapping adverse phenomena, including, but not limited to, unemployment, poverty, helplessness as regards childcare and upbringing matters, addictions, family violence, chronic illness or disability are reflected in problems within a family. The foregoing calls for a greater support provided by social services to the multiproblem families.
\end{abstract}

One of the new forms of helping the multi-problem families is family assistantship that was introduced under the
Act of 9 June 2011 concerning family support and alternative care systems. Family assistant is responsible for carrying out individualized, in-depth work with a family experiencing difficulties in fulfilling the childcare and upbringing functions and is responsible for supporting them during the process of change. Professional support provided by a family assistant gives a chance to many families to overcome difficulties and prevents placement of children under alternative care.

Keywords: family assistant, support, multi-problem families

Wiele współczesnych rodzin boryka się z problemami, które zaburzają poszczególne sfery ich funkcjonowania i generują trudności w realizacji funkcji przypisanych rodzinie. Mnogość nakładających się w niektórych rodzinach niekorzystnych zjawisk, m.in. bezrobocia, ubóstwa, biedy, bezradności w opiece nad 
dziećmi, uzależnień i przemocy, powoduje, że nie są one w stanie samodzielnie przezwyciężyć trudności i wymagają zwiększonego wsparcia służb społecznych, zwłaszcza gdy mają trudności w realizacji ról rodzicielskich a dzieci zagrożone są umieszczeniem poza rodziną. W takich przypadkach zindywidualizowaną, pogłębioną pracę $\mathrm{z}$ rodziną $\mathrm{z}$ wieloma problemami prowadzi asystent rodziny. Jego zadaniem jest zachęcanie rodziny do zmiany i wspomaganie jej w tym procesie, a finalnym celem pracy jest osiągnięcie przez rodzinę samodzielności.

\section{Idea asystentury rodziny}

Pierwsze polskie programy wsparcia i pomocy rodzinie oparte na idei asystentury zostały zrealizowane w latach 2006-2007 i stanowiły tzw. dobre praktyki ${ }^{1}$. W ich wprowadzeniu korzystano z doświadczeń krajów Europy Zachodniej, Stanów Zjednoczonych i Kanady, gdzie asystowanie było popularną formą wsparcia znaną pod nazwami coaching, job-coaching, life-coaching, akompaniowanie, towarzyszenie, mentoring, asysta, specjalizacja pracy socjalnej jako rodzaj środowiskowej pracy socjalnej lub intensywna praca socjalna ${ }^{2}$. W 2007 roku projekt „Asystent rodziny” zrealizowany w Miejskim Ośrodku Pomocy Społecznej w Sopocie zdobył wyróżnienie Ministra Pracy i Polityki Społecznej za wybitnie nowatorskie rozwiązania w pomocy społecznej, co przyczyniło się do popularyzacji tej formy pracy z rodziną. W 2010 roku asystenci pracowali w kilkudziesięciu ośrodkach pomocy społecznej, ośrodkach pomocy rodzinie, powiatowych centrach pomocy rodzinie i organizacjach pozarządowych. Przed wprowadzeniem Ustawy z dnia 9 czerwca 2011 r. o wspieraniu rodziny i systemie pieczy zastępczej asystentura rodziny najczęściej realizowana była w ramach projektów systemowych, finansowanych z funduszy europejskich, znacznie rzadziej finansowały ją ze środków własnych lub ministerialnych ośrodki pomocy społecznej ${ }^{3}$.

Jak wskazuje Izabela Krasiejko, twórcom pierwszych programów z wykorzystaniem asystentury przyświecało przekonanie o potrzebie pomocy rodzinom przeżywającym trudności jeszcze na poziomie profilaktyki, zanim dziecko trafi do placówki opiekuńczo-wychowawczej. Przemawiały za tym także niższe koszty środowiskowej pracy profilaktycznej. Brak cierpliwości w oczekiwaniu

1 I. Krasiejko, Metodyka działania asystenta rodziny. Różne modele pracy socjalnej i terapeutycznej z rodzina, Katowice 2012, s. 95-96.

2 A. Dębska-Cenian, Asystowanie - rozważania na temat istoty tego silnie zindywidualizowanego wsparcia, [w:] Asystentura rodziny - nowatorska metoda pomocy społecznej w Polsce, pod red. M. Szpunar, Gdynia 2010, s. 77.

3 I. Krasiejko, Metodyka działania asystenta..., dz. cyt., s. 96-97. 
na systemowe zmiany w pomocy społecznej oraz przekonanie, że oddzielenie świadczeń finansowych od pracy socjalnej z rodziną i prowadzenie jej w środowisku zamieszkania klienta przyniosą wymierne korzyści, sprzyjało podejmowaniu pionierskich na polskim gruncie działań z wykorzystaniem asystentów ${ }^{4}$. Istotnym czynnikiem przyczyniającym się do powstania asystentury rodziny była także duża liczba rodzin, które po transformacji ustrojowej nie radziły sobie ze zmienioną rzeczywistością i niekorzystnymi zjawiskami, tj. bezrobociem, ubóstwem, biedą, co rodziło konieczność faktycznej pomocy dzieciom i rodzinie. Pojawiała się zatem potrzeba wyodrębnienia nowych pracowników wśród istniejących już profesji społecznych lub powołania nowych, których zadaniem byłoby intensywne wspieranie rodzin $\mathrm{w}$ radzeniu sobie $\mathrm{z}$ różnego rodzaju trudnościami, zwłaszcza problemami opiekuńczo-wychowawczymi ${ }^{5}$.

Najważniejszymi cechami asystentury są: indywidualizacja pracy wynikająca z małej liczby odbiorców i pogłębionej diagnozy ich deficytów i zasobów oraz możliwości kierowania dedykowanego wsparcia, opartego najczęściej o instrumenty aktywnej integracji ${ }^{6}$. W definicji Anny Dunajskiej, Darii Dunajskiej i Beaty Klein asystowanie to kompleksowe działanie polegające na towarzyszeniu $\mathrm{z}$ zachowaniem profesjonalnych relacji, a asystent to „osoba, która towarzyszy klientowi w pokonywaniu jego życiowych trudności, pracuje na zasobach klienta, udziela wsparcia, motywuje rodzinę do zmiany niekorzystnej dla niej sytuacji i poprawy funkcjonowania”. Według Izabeli Krasiejko asystentura polega na „towarzyszeniu rodzinie $\mathrm{z}$ dziećmi w poszukiwaniu rozwiązań trudnej sytuacji życiowej, z wykorzystaniem mocnych stron członków rodziny, zasobów rodziny pochodzenia i rodziny dalszej, społeczności lokalnej i zasobów instytucjonal-

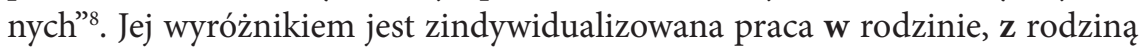
i dla rodziny ${ }^{9}$. Asystentura polega na obecności, towarzyszeniu, uczestniczeniu i służeniu wsparciem ${ }^{10}$. Jej istotą jest zmienianie stosunku rodziny do własnej sprawczości, zwiększanie poczucia wpływu rodziny na rzeczywistość, a także podnoszenie samooceny. Asystentura ma zatem służyć rozwojowi kompetencji

4 I. Krasiejko, Metodyka działania asystenta..., dz. cyt., s. 96-97.

5 D. Rynkowska, M. Artymiak, Mediacje w pracy socjalnej, Rzeszów 2014, s. 39.

A. Dębska-Cenian, Asystowanie..., dz. cyt., s. 80.

I. Krasiejko, Metodyka działania asystenta..., dz. cyt., s. 93-94.

\& I. Krasiejko, Idea asystentury rodziny, http://asystentrodziny.info/strona-glowna/ (dostęp: 21.11.2015).

9 A. Kotlarska-Michalska, Praca socjalna $w$ rodzinie, $z$ rodzina $i$ dla rodziny $w$ perspektywie ról zawodowych pracownika socjalnego i asystenta rodziny, [w:] Asystent rodzinny. Nowy zawód i nowa usługa $w$ systemie wspierania rodzin. Od opieki i pomocy do wsparcia, pod red. A. Żukiewicza, Kraków 2011, s. 68-72.

10 I. Krasiejko, Rola $i$ zadania asystentów rodziny oraz postulaty zmian $w$ Ustawie o wspieraniu rodziny i systemie pieczy zastępczej, Częstochowa 2015, s. 4. 
całej rodziny i jej poszczególnych członków, osiąganiu wyznaczonych celów i wzbudzaniu wiary we własne możliwości, a także motywowaniu do podejmowania działań, które dotychczas uważane były za niemożliwe do wykonania. Współpraca asystenta z rodziną ma więc przede wszystkim na celu usamodzielnienie się rodziny i pozostawienie w niej dzieci, z równoczesnym zapewnieniem im poczucia bezpieczeństwa i stabilnego rozwoju ${ }^{11}$.

Asystent rodziny obejmuje wsparciem dwa rodzaje rodzin:

- rodziny wychowujące dzieci - celem wsparcia jest poprawa funkcjonowania rodziny poprzez podejmowanie działań profilaktycznych zapobiegających umieszczeniu dziecka w pieczy zastępczej;

- rodziny, których dziecko przebywa w pieczy zastępczej - celem wsparcia jest poprawa funkcjonowania rodziny poprzez podejmowanie działań zmierzających do powrotu dziecka do rodziny ${ }^{12}$.

\section{Asystent rodziny w świetle przepisów prawa}

Ustawa z dnia 9 czerwca 2011 r. o wspieraniu rodziny i systemie pieczy zastępczej wprowadziła nową profesję pracowników służb społecznych - asystentów rodziny. Za rozwiązaniem tym przemawiała konieczność zapewnienia pomocy rodzinie przeżywającej trudności w wypełnianiu funkcji opiekuńczo-wychowawczych, aby nie dopuścić do zabrania dziecka z rodziny lub zapewnić mu szybki powrót do rodziny biologicznej w sytuacji okresowego umieszczenia w środowisku zastępczym. Ze wsparcia asystenta mogą korzystać wszystkie rodziny mające trudności w wykonywaniu funkcji rodzicielskich, bez względu na sytuację dochodową.

Zgodnie z zamiarem ustawodawcy praca asystenta rodziny powinna skupiać się na aktywnym wspieraniu rodziny wychowującej dzieci, borykającej się $\mathrm{z}$ problemami, $\mathrm{z}$ którymi nie może poradzić sobie samodzielnie, $\mathrm{w}$ tym także pomoc rodzinom, które ubiegają się o odzyskanie władzy rodzicielskiej. Celem pracy asystenta jest osiągnięcie przez wspieraną rodzinę podstawowego poziomu stabilności życiowej, co umożliwi wychowywanie dzieci, w tym powrót dziecka do rodziny biologicznej w sytuacji umieszczenia go w środowisku zastępczym ${ }^{13}$. Wsparcie asystenta ustaje wraz $\mathrm{z}$ osiągnięciem przez rodzinę samodzielne-

11 I. Krasiejko, Metodyka działania asystenta..., dz. cyt., s. 94.

12 B. Kowalczyk, Modele pracy asystenta rodziny $i$ wspótpracy z pracownikiem socjalnym, „Praca Socjalna” (2012) 4, s. 5.

13 Informacja Rady Ministrów o realizacji w roku 2012 Ustawy z dnia 9 czerwca 2011 r. o wspieraniu rodziny i systemie pieczy zastępczej, Dz.U. z 2012 r., poz. 135 z późn. zm., s. 12, https://www.mpips.gov.pl/wsparcie-dla-rodzin-z-dziecmi/opieka-zastepcza-nad-dziec- 
go, prawidłowego sprawowania opieki nad dzieckiem, a nadrzędnym celem jest niedopuszczenie do oderwania dzieci od środowiska rodziny biologicznej i rozerwania więzi z rodzicami ${ }^{14}$.

Asystent rodziny może być zatrudniony w jednostce organizacyjnej gminy, która organizuje pracę z rodziną, lub w instytucji, której gmina zleciła organizację pracy z rodziną. Do końca 2014 roku powołanie asystenta rodziny było zadaniem fakultatywnym dla gmin. Od 1 stycznia 2015 roku zatrudnienie asystenta jest obligatoryjne. Zgodnie z ustawą z 9 czerwca 2011 roku asystent rodziny może wykonywać pracę $\mathrm{w}$ ramach stosunku pracy w systemie zadaniowego czasu pracy lub umowy o świadczenie usług, do której stosuje się przepisy dotyczące zlecenia (art. 17.2). Asystent nie może łączyć swojej pracy z wykonywaniem obowiązków pracownika socjalnego w gminie, w której jest zatrudniony (art. 17.3), nie może także prowadzić postępowań z zakresu świadczeń realizowanych przez gminę (art. 17.4).

Zgodnie $\mathrm{z}$ art. 12 ustawy asystentem rodziny może być osoba, która ma:

- wykształcenie wyższe na kierunku pedagogika, psychologia, socjologia, nauki o rodzinie, praca socjalna;

- wykształcenie wyższe na dowolnym kierunku uzupełnione szkoleniem z zakresu pracy z dziećmi lub rodziną i udokumentuje co najmniej roczny staż pracy $\mathrm{z}$ dziećmi lub rodziną lub uzupełnione studiami podyplomowymi obejmującymi zakres programowy szkolenia określony na podstawie ust. 3 ustawy i udokumentuje co najmniej roczny staż pracy z dziećmi lub rodziną;

- wykształcenie średnie i szkolenie z zakresu pracy z dziećmi lub rodziną i udokumentuje co najmniej 3-letni staż pracy z dziećmi lub rodziną.

Wymogi dodatkowe określają, że asystentem może być osoba, która nie była lub nie jest pozbawiona władzy rodzicielskiej, władza rodzicielska nie jest jej zawieszona lub ograniczona, wypełnia obowiązek alimentacyjny (jeśli go ma) oraz nie była skazana prawomocnym wyrokiem za umyślne przestępstwo lub umyślne przestępstwo skarbowe (art. 12.1.2-4).

Zadania asystenta rodziny, określone w art. 15 ustawy, można pogrupować jako działania podejmowane $\mathrm{w}$ pięciu obszarach: planowania pracy $\mathrm{z}$ rodziną, działań w obszarze ekonomiczno-socjalnym, opiekuńczo-wychowawczym, społecznym oraz współpracy z innymi podmiotami działającymi na rzecz dziecka i rodziny ${ }^{15}$. Obszar planowania pracy z rodziną obejmuje: opracowanie i realizację planu pracy z rodziną we współpracy z członkami rodziny i w konsulta-

\footnotetext{
kiem/sprawozdania-z-realizacji-ustawy-o-wspieraniu-rodziny-i-systemie-pieczy-zasteczej/ (dostęp: 21.11.2015).

14 MBCenter, Poradnik asystenta rodziny, s. 5, 9, gopstychowo.naszbip.pl/upload/files/391380869505-1.pdf (dostęp: 21.11.2015).

15 MBCenter, Poradnik asystenta rodziny, s. 8, 11-16.
} 
cji z pracownikiem socjalnym (art. 15.1.1) oraz opracowanie, we współpracy z członkami rodziny i koordynatorem rodzinnej pieczy zastępczej, planu pracy $\mathrm{z}$ rodziną, który jest skoordynowany z planem pomocy dziecku umieszczonemu w pieczy zastępczej (art. 15.1.2). W obszarze ekonomiczno-socjalnym zadania asystenta rodziny to: udzielanie pomocy rodzinom w poprawie ich sytuacji życiowej, w tym w zdobywaniu umiejętności prawidłowego prowadzenia gospodarstwa domowego (art. 15.1.3), udzielanie pomocy rodzinom w rozwiązywaniu problemów socjalnych (art. 15.1.4), motywowanie członków rodzin do podnoszenia kwalifikacji zawodowych (art. 15.1.8), udzielanie pomocy w poszukiwaniu, podejmowaniu i utrzymywaniu pracy zarobkowej (art. 15.1.9). W obszarze opiekuńczo-wychowawczym zadania asystenta rodziny powinny skupiać się na: udzielaniu pomocy rodzinom w rozwiązywaniu problemów psychologicznych (art. 15.1.5), udzielaniu pomocy rodzinom w rozwiązywaniu problemów wychowawczych z dziećmi (art. 15.1.6), motywowaniu do udziału w zajęciach grupowych dla rodziców, mających na celu kształtowanie prawidłowych wzorów rodzicielskich i umiejętności psychospołecznych (art. 15.1.10), udzielaniu wsparcia dzieciom, w szczególności poprzez udział w zajęciach psychoedukacyjnych (art. 15.1.11), prowadzeniu indywidualnych konsultacji wychowawczych dla rodziców i dzieci (art. 15.1.13), podejmowaniu działań interwencyjnych i zaradczych w sytuacji zagrożenia bezpieczeństwa dzieci i rodzin (art. 15.1.12). W obszarze społecznym zadaniem asystenta jest wspieranie aktywności społecznej rodzin (art. 15.1.7), zaś w obszarze współpracy z innymi podmiotami: współpraca z jednostkami administracji rządowej i samorządowej, właściwymi organizacjami pozarządowymi oraz innymi podmiotami i osobami specjalizującymi się w działaniach na rzecz dziecka i rodziny (art. 15.1.18) oraz współpraca z zespołem interdyscyplinarnym lub grupą roboczą bądź innymi podmiotami, których pomoc uzna za niezbędną (art. 15.1.19). Dodatkowo do zadań asystenta należą także: prowadzenie dokumentacji dotyczącej pracy z rodziną (art. 15.1.14), dokonywanie okresowej oceny sytuacji rodziny, nie rzadziej niż co pół roku, i przekazywanie tej oceny podmiotowi zatrudniającemu (art. 15.1.15), sporządzanie na wniosek sądu opinii o rodzinie i jej członkach (art. 15.1.17) oraz monitorowanie funkcjonowania rodziny po zakończeniu pracy $\mathrm{z}$ rodziną (art. 15.1.16).

Asystent prowadzi pracę z rodziną w miejscu jej zamieszkania lub w miejscu, które zostanie przez rodzinę wskazane (art. 14). Liczba rodzin, z którymi asystent rodziny może prowadzić pracę w jednym czasie, jest uzależniona od stopnia trudności wykonywanych zadań, jednak nie może przekroczyć 15 (art. 15.4), 
wcześniej asystent mógł pracować równocześnie z 20 rodzinami ${ }^{16}$. Asystent kierowany jest do rodziny na wniosek pracownika socjalnego, który po dokonaniu analizy sytuacji rodziny występuje z odpowiednim wnioskiem do kierownika ośrodka pomocy społecznej.

W ciągu trzech lat istnienia instytucji asystenta rodziny obserwowany jest stopniowy wzrost liczby asystentów prowadzących pracę $\mathrm{z}$ rodziną. $\mathrm{W}$ tabeli 1 przedstawiono liczbę asystentów rodziny w poszczególnych województwach w latach 2012-2014.

Tabela 1. Asystenci rodziny według województw w latach 2012-2014

\begin{tabular}{|l|r|r|r|}
\hline \multicolumn{1}{|c|}{ Rok } & 2012 & 2013 & 2014 \\
\hline Liczba asystentów rodziny ogółem & 2105 & 3012 & 3393 \\
\hline dolnośląskie & 171 & 194 & 223 \\
\hline kujawsko-pomorskie & 37 & 203 & 211 \\
\hline lubelskie & 112 & 199 & 244 \\
\hline lubuskie & 86 & 122 & 131 \\
\hline łódzkie & 96 & 160 & 190 \\
\hline małopolskie & 145 & 226 & 241 \\
\hline mazowieckie & 226 & 360 & 402 \\
\hline opolskie & 33 & 56 & 67 \\
\hline podkarpackie & 122 & 157 & 194 \\
\hline podlaskie & 32 & 73 & 90 \\
\hline pomorskie & 126 & 198 & 234 \\
\hline śląskie & 194 & 254 & 299 \\
\hline świętokrzyskie & 85 & 123 & 143 \\
\hline warmińsko-mazurskie & 190 & 200 & 216 \\
\hline wielkopolskie & 194 & 289 & 291 \\
\hline zachodniopomorskie & 156 & 198 & 217 \\
\hline
\end{tabular}

16 Ustawa z dnia 25 lipca 2014 r. o zmianie ustawy o wspieraniu rodziny i systemie pieczy zastępczej oraz niektórych innych ustaw, Dz.U. z 2014 r., poz. 1188. 
Źródło: Informacja Rady Ministrów o realizacji ustawy z dnia 9 czerwca 2011 r. o wspieraniu rodziny i systemie pieczy zastępczej za rok 2012, 2013, 2014, https://www.mpips.gov.pl/ wsparcie-dla-rodzin-z-dziecmi/opieka-zastepcza-nad-dzieckiem/sprawozdania-z-realizacji-ustawy-o-wspieraniu-rodziny-i-systemie-pieczy-zasteczej/ (dostęp: 21.11.2015).

Za charakterystyczne cechy pracy asystenta rodziny Barbara Kowalczyk uznaje: intensywne oddziaływania krótkoterminowe, pracę głównie w środowisku zamieszkania rodziny, pracę metodą towarzyszenia, zadaniowy czas pracy oraz czas pracy dostosowany do potrzeb rodziny, objęcie wsparciem maksymalnie 20 środowisk, oddzielenie od przyznawania świadczeń materialnych ${ }^{17}$. Jan Adam Malinowski wskazuje na funkcje pełnione przez asystenta rodziny, wyróżniając kolejno: wsparcia psychiczno-emocjonalnego, diagnostyczno-monitorującą, opiekuńczą, doradczą, mediacyjną, wychowawczą, motywująco-aktywizującą oraz koordynacji działań skierowanych na rodzinę ${ }^{18}$.

\section{Praca asystenta z rodzina z wieloma problemami}

Asystent rodziny podejmuje pracę przede wszystkim z rodzinami przeżywającymi trudności w realizacji funkcji opiekuńczo-wychowawczych. W wielu przypadkach są to rodziny borykające się z mnogością nakładających się wzajemnie na siebie problemów, które są zagrożeniem dla jej prawidłowego funkcjonowania. Część z tych rodzin nadal nie odnalazła się w warunkach transformacji ustrojowej, a dokonujące się zmiany społeczno-ekonomiczne, w tym przemiany na rynku pracy, spowodowały nasilenie się niekorzystnych zjawisk, tj. bezrobocia, ubóstwa, biedy, uzależnień, przemocy domowej ${ }^{19}$. Splot tych czynników powoduje, że spora liczba rodzin nie radzi sobie z wypełnianiem zadań rodzicielskich, a dodatkowym obciążeniem staje się także tzw. wyuczona bezradność, związana z przekonaniem o braku szans na samodzielne zabezpieczenie własnych potrzeb ${ }^{20}$. Rodziny długotrwale borykające się z różnego rodzaju

17 B. Kowalczyk, Modele pracy asystenta..., dz. cyt., s. 14.

18 J. A. Malinowski, Role, funkcje i zadania asystenta rodzinnego, [w:] Asystent rodzinny. Nowy zawód i nowa ustuga..., dz. cyt., s. 40.

19 A. Chmielewska, Środowisko rodzinne jako źródło trudności i wsparcia, [w:] Wielość spojrzeń na małżeństwo i rodzinę, red. A. Kwak, M. Bieńko, Warszawa 2012, s. 179-180; J. Matejek, O. Wyżga, Wybrane problemy patologii społecznych zagrożeniem funkcjonowania współczesnej rodziny, [w:] Rodzina wobec zagrożeń, pod red. M. Dudy, Kraków 2008, s. $107-111$.

20 I. Krasiejko, Metodyka działania asystenta..., dz. cyt., s. 18-19. 
nakładającymi się na siebie problemami, które komplikują ich życie codzienne, objęte zostały pojęciem rodziny $z$ wieloma problemami ${ }^{21}$. Termin ten odnosi się do rodzin długotrwale korzystających z pomocy społecznej, ze złożoną sytuacją życiową, dla których alternatywnymi określeniami są: rodzina dysfunkcjonalna, wieloproblemowa, patologiczna, specjalnej troski ${ }^{22}$. Jednak w odróżnieniu od wymienionych określeń używanie terminu „rodzina z wieloma problemami” zdaniem Izabeli Krasiejko pozwala na oddzielenie problemu od człowieka, dążenie do podmiotowego traktowania klienta oraz unikanie etykiet, co skutkuje pracą na zasobach rodziny, a nie tylko podkreślaniem jej braków ${ }^{23}$.

Wśród rodzin z wieloma problemami zgłaszanymi do programów pomocowych dominują takie, które długotrwale pozostają w systemie pomocy społecznej. Przed objęciem wsparciem asystenta najczęściej od wielu lat korzystały z pomocy służb społecznych lub były przedmiotem interwencji m.in. kuratorów, pracowników socjalnych, pracowników szkoły, policji ${ }^{24}$. Do wielu problemów takich rodzin zazwyczaj należą: problemy opiekuńczo-wychowawcze, bezrobocie, ubóstwo, alkoholizm lub nadużywanie alkoholu, przemoc, długotrwała choroba, niepełnosprawność ${ }^{25}$.

Małgorzata Szpunar wskazuje z kolei na biedę oraz sprzężone z tym zjawiskiem bezrobocie, niezaradność życiową, nieumiejętność prowadzenia gospodarstwa domowego, uzależnienia, wielodzietność, samotne macierzyństwo, przemoc domową. Rodziny te często dziedziczą statusy społeczne i są kolejnym pokoleniem korzystającym z pomocy społecznej ${ }^{26}$. Dodatkowo przyczyną trudności może być wyuczona bezradność, której źródła mogą odnosić się do długotrwałego bezrobocia $\mathrm{z}$ wieloma porażkami przy poszukiwaniu pracy, choroby i niepełnosprawności, uzależnienia oraz zadłużenia ${ }^{27}$. Wsparcie asystenta ma zatem na celu poprawę funkcjonowania całej rodziny, lepsze radzenie sobie rodziców w sytuacjach życiowych oraz prawidłowe pełnienie ról społecznych. Asystent ma za zadanie doprowadzić do zmian w dotychczasowym życiu rodziny, gdyż konsekwencją braku zmiany jest odebranie dzieci i umieszczenie ich poza rodziną ${ }^{28}$. Jak piszą Agata Matysiak-Błaszczyk i Mi-

21 M. Szpunar, Charakterystyka rodzin z wieloma problemami, [w:] Asystentura rodziny - nowatorska metoda..., dz. cyt., s. 49; I. Krasiejko, Metodyka działania asystenta..., dz. cyt., s. 11.

22 M. Szpunar, Charakterystyka rodzin..., dz. cyt., s. 49.

23 I. Krasiejko, Metodyka działania asystenta..., dz. cyt., s. 11.

24 I. Krasiejko, Metodyka działania asystenta..., dz. cyt., s. 15-16.

25 I. Krasiejko, Metodyka działania asystenta..., dz. cyt., s. 15-16.

26 M. Szpunar, Charakterystyka rodzin..., dz. cyt., s. 49-50.

27 I. Krasiejko, Metodyka działania asystenta..., dz. cyt., s. 22.

28 I. Krasiejko, Metodyka działania asystenta..., dz. cyt., s. 19. 
rosława Ściupider, asystent powinien pracować z rodziną, opierając się na jej mocnych stronach, wydobywając z członków rodziny potencjały, które mogą być pomocne w przezwyciężaniu trudności, gdyż rodziny te często nie widzą możliwości zmiany w swoim życiu. Tym samym idea asystentury rodziny powinna opierać się na zasadach empowermentu rodzin (wzmocnienia), w celu ich usamodzielnienia i uczenia umiejętności, które pozwolą na radzenie sobie w trudnych sytuacjach ${ }^{29}$.

Krasiejko, omawiając pracę asystenta rodziny, podkreśla socjalno-wychowawczy charakter tej pracy oraz jej wymiar terapeutyczny przy jednoczesnym koordynowaniu działań innych służb społecznych działających na rzecz danej rodziny oraz administrowaniu usług związanych $z$ danym przypadkiem ${ }^{30}$. Praca socjalno-wychowawcza z rodziną może być prowadzona jako ratownictwo, opieka i pomoc. Asystent rodziny może także pomagać w przywracaniu wewnętrznej stabilizacji rodziny, jednak nie w formie psychoterapii (prowadzonej przez wykwalifikowanego terapeutę), lecz interwencji psychosocjalnej ${ }^{31}$. Interdyscyplinarny charakter pracy asystenta rodziny podkreśla Izabela Nowak, pisząc, że jest ona użyteczna, gdy asystent działa na pograniczu trzech ról: pracownika socjalnego, trenera umiejętności życiowych i doradcy świadczącego pomoc psychologiczną, rozumianą jako przygotowanie rodziny do interwencji specjalistów z zewnątrz. Pełnienie tych ról uzależnione jest od potrzeb rodziny oraz momentu współpracy asystenta $\mathrm{z}$ rodziną, dostosowującego w sposób plastyczny role do wypełnianych zadan ${ }^{32}$.

Zdaniem Anny Kotlarskiej-Michalskiej praca asystenta rodziny to zindywidualizowana praca $\mathbf{w}$ rodzinie, $\mathbf{z}$ rodziną i dla rodziny. W sytuacji gdy rodzina nie potrafi działać, rodzice mają deficyty w przygotowaniu do ról rodzicielskich lub zaburzony ich obraz, ma zastosowanie model pracy w rodzinie, odnoszący się do treningu w zakresie podstawowych ról. Praca $\mathbf{z}$ rodziną prowadzona jest jako wsparcie w deficytowych sferach, w sytuacji gdy rodzina ma świadomość zakresu ról i motywację do działania, ale barierą są obiektywne trudności lub brak odpowiednich środków. Praca dla rodziny prowadzona jest z kolei w sytuacji, gdy rodzina ma deficyty w dziedzinie motywacji do działań - wsparcie rodziny ma wówczas na celu ocalenie jej jako instytucji i grupy społecznej,

29 A. Matysiak-Błaszczyk, M. Ściupider, Poznańskie doświadczenia asystentury rodzinnej, [w:] Pomoc - wsparcie społeczne - poradnictwo. Od teorii do praktyki, pod red. M. Piorunek, Toruń 2010, s. 359.

30 I. Krasiejko, Metodyka działania asystenta..., dz. cyt., s. 137

31 I. Krasiejko, Metodyka działania asystenta..., dz. cyt., s. 139.

32 I. Nowak, Asystentura rodziny z perspektywy praktyka, „Praca Socjalna” (2012) 4, s. 108. 
poprzez działania ukierunkowane na czynności integracyjne i rekonstruujące więzi społeczne ${ }^{33}$.

W 2012 roku wsparciem asystenta objęto ogółem 18947 rodzin, z czego 3,6 proc. do współpracy zostało zobowiązane przez sąd. W 2014 roku liczba rodzin objętych wsparciem, w tym nakazanym przez sąd, uległa podwojeniu. W tabeli 2 zaprezentowano szczegółowe dane za lata 2012-2014.

Tabela 2. Liczba rodzin objętych wsparciem asystenta rodziny w latach 2012-2014

\begin{tabular}{|l|c|c|c|}
\hline \multicolumn{1}{|c|}{ Rok } & 2012 & 2013 & 2014 \\
\hline $\begin{array}{l}\text { liczba rodzin objętych wsparciem asy- } \\
\text { stenta rodziny }\end{array}$ & 18947 & 31506 & 37876 \\
\hline $\begin{array}{l}\text { w tym na mocy decyzji sądu ro- } \\
\text { dzinnego }\end{array}$ & 693 & 1521 & 2368 \\
\hline
\end{tabular}

Źródło: Informacja Rady Ministrów o realizacji ustawy z dnia 9 czerwca 2011 r. o wspieraniu rodziny i systemie pieczy zastępczej za rok 2012, 2013, 2014, https://www.mpips.gov.pl/ wsparcie-dla-rodzin-z-dziecmi/opieka-zastepcza-nad-dzieckiem/sprawozdania-z-realizacji-ustawy-o-wspieraniu-rodziny-i-systemie-pieczy-zasteczej/ (dostęp: 21.11.2015).

Praca asystenta $\mathrm{z}$ rodziną $\mathrm{z}$ wieloma problemami w pierwszej kolejności powinna polegać na wspieraniu, wzmacnianiu, rzecznictwie, pokierowaniu, towarzyszeniu i kontrolowaniu ${ }^{34}$. Krasiejko podkreśla, że zadania realizowane przez asystenta, związane ze wspieraniem rodziny w procesie zmiany, powinny cechować się zatem odpowiednią kolejnością. W pierwszym rzędzie rodzina powinna otrzymać wsparcie informacyjne, emocjonalne i instrumentalne oraz towarzyszenie jej w sytuacjach dnia codziennego, w poszukiwaniu rozwiązań sytuacji trudnych, wyciąganiu wniosków z porażek oraz towarzyszeniu w czasie wizyt w instytucjach. Kolejnym krokiem powinna być pedagogizacja rodziców, w tym modelowanie i trening umiejętności opiekuńczo-wychowawczych, oraz praca socjalna z rodziną i wsparcie rzeczowe. Jako ostatnie działania wymieniane są: monitorowanie, kontrolowanie i działania zaradcze, prowadzone jako interwencja w przypadku zastania w miejscu zamieszkania rodziny sytuacji zagrażających bezpieczeństwu dziecka. Asystent rodziny powinien zatem działać przede wszystkim w zakresie informowania i wsparcia psychologicznego, interwencje

\footnotetext{
${ }^{33}$ A. Kotlarska-Michalska, Praca socjalna $w$ rodzinie..., dz. cyt., s. 68-72.

34 I. Krasiejko, Metodyka działania asystenta..., dz. cyt., s. 177.
} 
prowadzić w wyjątkowych przypadkach, zaś monitorowanie w ograniczonym zakresie $^{35}$.

Istotne znaczenie ma także kolejność podejmowanych działań w ramach poszczególnych etapów pracy asystenta rodziny. Sekwencja prowadzonych działań zaproponowana przez Izabelę Krasiejko powinna skupiać się na:

- rozwiązaniu codziennych problemów socjalnych rodziny (zwiększenie zasobów finansowych rodziny na bieżące funkcjonowanie, sprawy mieszkaniowe, zaległe i bieżące sprawy urzędowe, dostęp do lekarzy i innych specjalistów, realizacja uprawnień, pomoc dzieciom w zakresie opieki po zajęciach szkolnych i wyżywienia oraz podczas odrabiania lekcji, współpraca z służbami i instytucjami: kuratorem, szkołą, administracją, pomocą społeczną itp.);

- pracy na rzecz podnoszenia umiejętności opiekuńczo-wychowawczych rodziców i realizacji obowiązków na rzecz domu i rodziny;

- pracy na rzecz uzupełnienia wykształcenia i poszukiwania pracy przez członków rodziny. Dalsze działania asystenta to np. pomoc w poprawieniu relacji wewnątrzrodzinnych i międzysąsiedzkich, motywowanie do udziału w terapii uzależnień, szkoleniach doskonalących kompetencje i umiejętności wychowawcze, korzystanie z poradnictwa rodzinnego, aktywizacja zawodowa poprzez kursy, podnoszenie umiejętności opiekuńczo-wychowawczych, praca nad autorytetem rodziców, praca nad umiejętnością gospodarowania budżetem domowym, praca nad higieną, podnoszeniem umiejętności prowadzenia gospodarstwa domowego, zwiększanie poczucia wartości, samodzielności i zaradności rodziców ${ }^{36}$. Preferowanymi metodami pracy asystenta rodziny są zatem: edukacja, trening i poradnictwo ${ }^{37}$. Jak wskazuje raport Najwyższej Izby Kontroli podsumowujący pierwsze lata działalności asystentów rodzinnych, w praktyce najczęstszymi formami wsparcia były: konsultacje i rozmowy motywujące do utrzymania abstynencji, spędzania czasu z dziećmi i rodziną, utrzymania czystości oraz podjęcia aktywności na rynku pracy. Prowadzone były także treningi w zakresie racjonalnego gospodarowania budżetem domowym. Asystenci służyli ponadto wsparciem i pomocą w załatwianiu spraw urzędowych, prowadzili rozmowy z dyrektorami szkół i wychowawcami oraz motywowali do podjęcia konsultacji lekarskich, pomagali w poszukiwaniu zatrudnienia oraz organizacji pomocy

\footnotetext{
5 I. Krasiejko, Rola i zadania asystentów..., dz. cyt., s. 4-5.

I. Krasiejko, Metodyka działania asystenta..., dz. cyt., s. 110-111.

I. Krasiejko, Metodyka działania asystenta..., dz. cyt., s. 176.
} 
psychologicznej i prawnej. W sytuacji przemocy domowej współpracowali przy wszczęciu procedury Niebieskiej Karty ${ }^{38}$.

Praca asystenta $\mathrm{z}$ rodziną $\mathrm{z}$ wieloma problemami nie jest działaniem krótkotrwałym, lecz rozciągniętym w czasie. Współpraca z rodziną może zakończyć się ze względu na osiągnięcie celów, zaprzestanie współdziałania przez rodzinę, zmianę metody pracy lub brak efektów. Ze sprawozdań z realizacji ustawy o wspieraniu rodziny wynika, że najczęstszym powodem zakończenia pracy $\mathrm{z}$ rodziną $\mathrm{w}$ danym roku było osiągnięcie celów: $\mathrm{w} 2012$ roku $-48,5$ proc. rodzin, w 2013 - 51 proc., w 2014 roku - 46 proc. Istotnym powodem zakończenia pracy było także zaprzestanie przez rodzinę współpracy z asystentem (odpowiednio: 24, 27 i 32 proc.). Trzecia grupa powodów wiąże się ze zmianą metody pracy (odpowiednio: 21, 13 i 11 proc.). Brak efektów pracy spowodował zakończenie pracy z asystentem w przypadku 6 proc. rodzin w 2012 roku, 9 proc. rodzin w 2013 roku oraz 11 proc. rodzin w 2014 roku $^{39}$.

\section{Podsumowanie}

Asystent rodziny prowadzi pracę z rodziną z wieloma problemami w środowisku lokalnym w jej miejscu zamieszkania. Objęte wsparciem rodziny najczęściej cechują się trudnościami w realizacji funkcji opiekuńczo-wychowawczych, nie radzą sobie z prowadzeniem gospodarstwa domowego, od lat korzystają z pomocy społecznej i doświadczają interwencji różnych służb społecznych. Współpraca $\mathrm{z}$ asystentem jest dla wielu $\mathrm{z}$ nich szansą na poprawę funkcjonowania i zatrzymania w niej dzieci, umieszczonych w środowisku zastępczym lub zagrożonych takim umieszczeniem. Efektywne wsparcie rodziny $\mathrm{z}$ wieloma problemami możliwe jest także dzięki współpracy asystenta $\mathrm{z}$ innymi podmiotami czy instytucjami działającymi na rzecz dziecka i rodziny oraz koordynacją wspólnie podejmowanych działań w zakresie pomocy konkretnej rodzinie.

38 Najwyższa Izba Kontroli, Funkcjonowanie asystentów rodziny $w$ świetle Ustawy o wspieraniu rodziny i systemie pieczy zastępczej, Warszawa 2015, s. 10.

39 Informacja Rady Ministrów o realizacji w roku 2012 Ustawy z dnia 9 czerwca 2011 r. o wspieraniu rodziny i systemie pieczy zastępczej, Dz.U. z 2012 r., poz. 135 z późn. zm., s. 15-16; Informacja Rady Ministrów o realizacji w roku 2013 Ustawy z dnia 9 czerwca 2011 r. o wspieraniu rodziny i systemie pieczy zastępczej, Dz.U. z 2012 r., poz. 135 z późn. zm., s. 9; Informacja Rady Ministrów o realizacji w roku 2014 Ustawy z dnia 9 czerwca 2011 r. o wspieraniu rodziny i systemie pieczy zastępczej, Dz.U. z 2015 r., poz. 332, s. 7, https://www.mpips.gov.pl/wsparcie-dla-rodzin-z-dziecmi/opieka-zastepcza-nad-dziec$\mathrm{kiem} /$ sprawozdania-z-realizacji-ustawy-o-wspieraniu-rodziny-i-systemie-pieczy-zasteczej/ (dostęp: 21.11.2015). 
Od momentu wprowadzenia asystenta rodziny w 2012 roku do systemu pomocy społecznej widoczna staje się potrzeba podejmowania zindywidualizowanej pracy z rodziną z wykorzystaniem asystentury rodzinnej. Stopniowo w całej Polsce wzrasta liczba asystentów, co może świadczyć o dużym zapotrzebowaniu na taką formę pogłębionej pomocy. Duża liczba rodzin z wieloma problemami objętych wsparciem asystenta rodzi z kolei konieczność ciągłego podnoszenia kwalifikacji zawodowych asystentów, gdyż proces profesjonalnego wsparcia jest przedsięwzięciem pomocowym realizowanym równocześnie $\mathrm{w}$ wielu sferach funkcjonowania rodziny i przynoszącym efekty dopiero w dłuższej perspektywie czasowej.

\section{Bibliografia}

Chmielewska A., Środowisko rodzinne jako źródło trudności i wsparcia, [w:] Wielość spojrzeń na matżeństwo i rodzinę, red. A. Kwak, M. Bieńko, Warszawa 2012, s. 177-198.

Dębska-Cenian A., Asystowanie - rozważania na temat istoty tego silnie zindywidualizowanego wsparcia, [w:] Asystentura rodziny - nowatorska metoda pomocy społecznej w Polsce, pod red. M. Szpunar, Gdynia 2010, s. 76-81.

Informacja Rady Ministrów o realizacji w roku 2012 Ustawy z dnia 9 czerwca 2011 r. o wspieraniu rodziny i systemie pieczy zastępczej, Dz.U. z 2012 r., poz. 135 z późn. zm., https:// www.mpips.gov.pl/wsparcie-dla-rodzin-z-dziecmi/opieka-zastepcza-nad-dzieckiem/ sprawozdania-z-realizacji-ustawy-o-wspieraniu-rodziny-i-systemie-pieczy-zasteczej/ (dostęp: 21.11.2015).

Informacja Rady Ministrów o realizacji w roku 2013 Ustawy z dnia 9 czerwca 2011 r. o wspieraniu rodziny i systemie pieczy zastępczej, Dz.U. z 2012 r., poz. 135 z późn. zm., https:// www.mpips.gov.pl/wsparcie-dla-rodzin-z-dziecmi/opieka-zastepcza-nad-dzieckiem/ sprawozdania-z-realizacji-ustawy-o-wspieraniu-rodziny-i-systemie-pieczy-zasteczej/ (dostęp: 21.11.2015).

Informacja Rady Ministrów o realizacji w roku 2014 Ustawy z dnia 9 czerwca 2011 r. o wspieraniu rodziny i systemie pieczy zastępczej, Dz.U. z 2015 r., poz. 332, https://www.mpips. gov.pl/wsparcie-dla-rodzin-z-dziecmi/opieka-zastepcza-nad-dzieckiem/sprawozdania-z-realizacji-ustawy-o-wspieraniu-rodziny-i-systemie-pieczy-zasteczej/ (dostęp: 21.11.2015).

Kotlarska-Michalska A., Praca socjalna $w$ rodzinie, $z$ rodzina i dla rodziny w perspektywie ról zawodowych pracownika socjalnego i asystenta rodziny, [w:] Asystent rodzinny. Nowy zawód i nowa usługa w systemie wspierania rodzin. Od opieki i pomocy do wsparcia, pod red. A. Żukiewicza, Kraków 2011, s. 55-74.

Kowalczyk B., Modele pracy asystenta rodziny i wspótpracy z pracownikiem socjalnym, „Praca Socjalna" (2012), s. 3-15. 
Krasiejko I., Idea Asystentury rodziny, http://asystentrodziny.info/strona-glowna/ (dostęp: 21.11.2015).

Krasiejko I., Metodyka działania asystenta rodziny. Różne modele pracy socjalnej i terapeutycznej z rodzina, Katowice 2012.

Krasiejko I., Rola i zadania asystentów rodziny oraz postulaty zmian w Ustawie o wspieraniu rodziny $i$ systemie pieczy zastępczej, Częstochowa 2015, http://asystentrodziny.info/ materialy/nowa-strona-1/ (dostęp: 21.11.2015).

Krasiejko I., Zawód asystenta rodziny w procesie profesjonalizacji. Wstęp do teorii i praktyki nowej profesji społecznej, Toruń 2013.

Malinowski J.A., Role, funkcje i zadania asystenta rodzinnego, [w:] Asystent rodzinny. Nowy zawód i nowa usługa w systemie wspierania rodzin. Od opieki i pomocy do wsparcia, pod red. A. Żukiewicza, Kraków 2011, s. 37-49.

Matejek J., Wyżga O., Wybrane problemy patologii społecznych zagrożeniem funkcjonowania wspótczesnej rodziny, [w:] Rodzina wobec zagrożeń, pod red. M. Dudy, Kraków 2008, s. $107-114$.

Matysiak-Błaszczyk A., Ściupider M., Poznańskie doświadczenia asystentury rodzinnej, [w:] Pomoc - wsparcie społeczne - poradnictwo. Od teorii do praktyki, pod red. M. Piorunek, Torun 2010, s. 355-372.

Najwyższa Izba Kontroli, Funkcjonowanie asystentów rodziny w świetle Ustawy o wspieraniu rodziny i systemie pieczy zastępczej, Warszawa 2015.

Nowak I., Asystentura rodziny z perspektywy praktyka, „Praca Socjalna” (2012) 4, s. 107-120.

MBCenter, Poradnik asystenta rodziny, gopstychowo.naszbip.pl/upload/files/391380869505-1. pdf (dostęp: 21.11.2015).

Rynkowska D., Artymiak M., Mediacje w pracy socjalnej, Rzeszów 2014.

Szpunar M., Charakterystyka rodzin z wieloma problemami, [w:] Asystentura rodziny - nowatorska metoda pomocy społecznej w Polsce, pod red. M. Szpunar, Gdynia 2010, s. 48-62.

Ustawa z dnia 25 lipca 2014 r. o zmianie ustawy o wspieraniu rodziny i systemie pieczy zastępczej oraz niektórych innych ustaw, Dz.U. z 2014 r., poz. 1188. 
4. Uniwersytet Papieski 